\title{
Imaging in median arcuate ligament syndrome
}

\author{
Yashant Aswani, Hemangini Thakkar, Karan Manoj Anandpara
}

Seth G S Medical College and KEM Hospital, Mumbai, Maharashtra, India

\section{Correspondence to}

Dr Yashant Aswani, aswaniyashant@gmail.com

Accepted 22 November 2015
To cite: Aswani $Y$, Thakkar H, Anandpara KM. BMJ Case Rep Published online: [please include Day Month Year] doi:10.1136/ bcr-2014-207856

\section{DESCRIPTION}

An 18-year-old man presented with a 7-month history of abdominal pain, particularly in the epigastrium, and weight loss of 14 pounds. Symptoms were aggravated post meals. An abdominal sonogram, upper gastroendoscopy and colonoscopy, were inconclusive. A contrast-enhanced CT of the abdomen revealed kinking of the proximal coeliac artery due to the median arcuate ligament, creating a hooked appearance with post-stenotic dilation (figure 1). A repeat sonography with Doppler revealed a normal calibre coeliac artery in inspiration with a peak systolic velocity (PSV) of $147 \mathrm{~cm} / \mathrm{s}$ (figure 2A). On the contrary, there was colour aliasing suggestive of post-stenotic turbulence in expiration with a PSV of $304 \mathrm{~cm} / \mathrm{s}$ (figure 2B). A diagnosis of median arcuate ligament syndrome was made. Surgical resection of the ligament led to relief of symptoms.

The median arcuate ligament is a fibrous sling that courses superior to the coeliac trunk origin. ${ }^{1}$ When it is abnormally low, it compresses the artery,

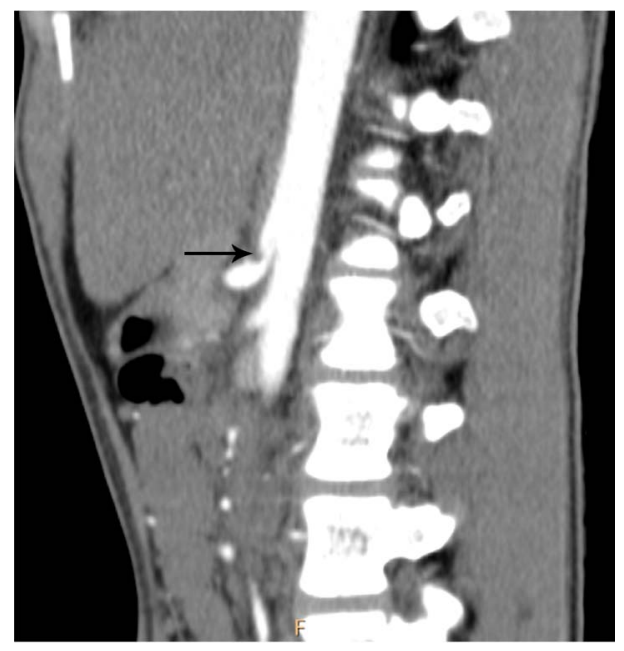

Figure 1 Contrast-enhanced CT of the abdomen, parasagittal reconstruction, showing kinking of the proximal coeliac artery, creating a hooked appearance (black arrow). There is post-stenotic dilation. but symptoms of mesenteric ischaemia are rarely seen. A typical patient is a young female with postprandial pain and weight loss. ${ }^{1}$ CT reveals acute angulation and proximal narrowing of the coeliac trunk with post-stenotic dilation. This hooked appearance differentiates it from atherosclerotic narrowing. ${ }^{12}$ The narrowing accentuates on expiration, as evidenced by increased flow velocity and turbulence on Doppler. ${ }^{2}$ A PSV of over $200 \mathrm{~cm} / \mathrm{s}$ during expiration or a ratio more than $3: 1$ of PSV of coeliac trunk to aorta in expiration is a Doppler criterion for diagnosis. ${ }^{2}$ The definitive diagnosis is, however, digital subtraction angiography. ${ }^{2}$

\section{Learning points}

Our case stresses the need to perform Doppler interrogation especially when grey scale findings are apparently normal. Screening of vascular causes of ischaemic pain can be easily performed with colour Doppler examination.

- Classic angiographic findings of median arcuate ligament syndrome include kinking of the proximal coeliac trunk with post-stenotic dilation. The narrowing worsens when the patient exhales. Doppler study reveals increase in peak systolic velocity with turbulent flow on exhalation as opposed to inspiratory flow patterns.

Competing interests None declared.

Patient consent Obtained.

Provenance and peer review Not commissioned; externally pee reviewed.

\section{REFERENCES}

1 Horton KM, Talamini MA, Fishman EK. Median arcuate ligament syndrome: evaluation with CT angiography. Radiographics 2005:25:1177-82.

2 Ozel A, Toksoy G, Ozdogan 0, et al. Ultrasonographic diagnosis of median arcuate ligament syndrome: a report of two cases. Med Ultrason 2012;14:154-7. 
Figure 2 (A) Colour Doppler with spectral analysis of the coeliac artery in inspiration reveals normal calibre and a peak systolic velocity of $147 \mathrm{~cm} / \mathrm{s}$.

(B) Colour Doppler and spectral analysis of coeliac artery on exhalation depicts colour aliasing (white arrow) suggestive of post-stenotic turbulent flow with a peak systolic velocity of $304 \mathrm{~cm} / \mathrm{s}$. There is widening of the spectral window.

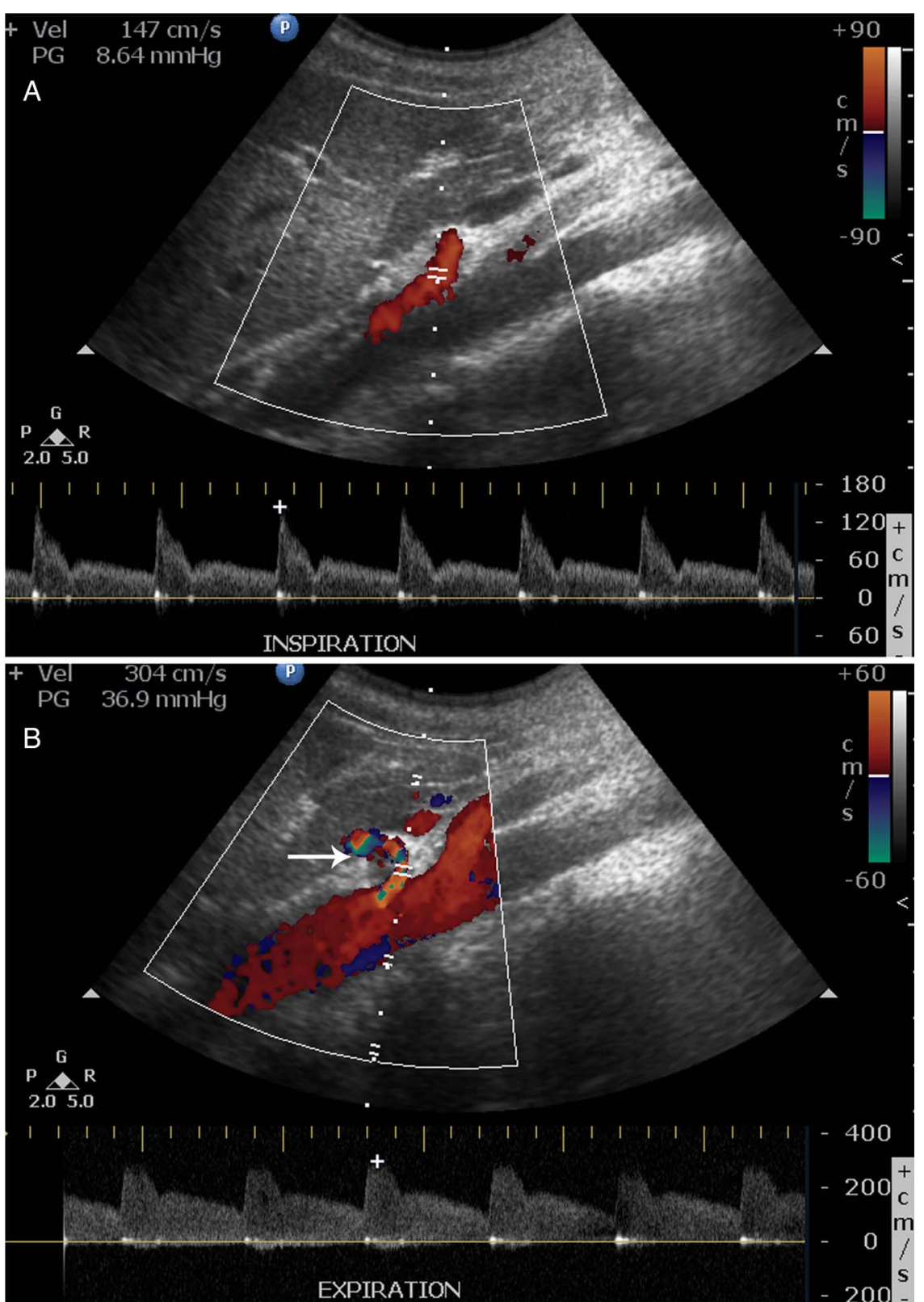

EXPIRATION

Copyright 2015 BMJ Publishing Group. All rights reserved. For permission to reuse any of this content visit

http://group.bmj.com/group/rights-licensing/permissions.

BMJ Case Report Fellows may re-use this article for personal use and teaching without any further permission.

Become a Fellow of BMJ Case Reports today and you can:

- Submit as many cases as you like

- Enjoy fast sympathetic peer review and rapid publication of accepted articles

- Access all the published articles

- Re-use any of the published material for personal use and teaching without further permission

For information on Institutional Fellowships contact consortiasales@bmjgroup.com

Visit casereports.bmj.com for more articles like this and to become a Fellow 